\title{
Molecular Characterization of Australian Isolates of Puccinia graminis f. sp. tritici Supports Long-Term Clonality but also Reveals Cryptic Genetic Variation
}

\author{
Jianping Zhang, Peng Zhang, Haydar Karaoglu, Robert F. Park ${ }^{\dagger}$
}

First, second, third, and fourth authors: University of Sydney, Plant Breeding Institute Cobbitty, Cobbitty, NSW 2570, Australia; first author: CSIRO Agriculture, GPO Box 1600, Canberra, ACT 2601, Australia; and first author: Henan Tianmin Seed Company Ltd., South Industrial District, Lankao, Henan, 475300, P. R. China.

Accepted for publication 13 May 2017.

\begin{abstract}
Long-term surveys of pathogenicity in Puccinia graminis f. sp. tritici in Australia have implicated mutation as a major source of virulence, at times leading to the demise of stem-rust-resistant wheat cultivars and substantial yield losses. Since 1925, these surveys have identified at least four occasions on which exotic isolates of $P$. graminis f. sp. tritici appeared in Australia, with each acting as a founding isolate that gave rise sequentially to derivative pathotypes via presumed single-step mutation. The current study examined the relationship between virulence and molecular patterns using simple-sequence repeat (SSR) markers on selected isolates of $P$. graminis f. sp. tritici collected in Australia during a 52-year period in order to propose an evolutionary pathway involving these isolates. Studies of SSR variability among this collection of isolates within a putative clonal lineage based on pathotype 21-0, first detected in 1954 (the "21/34 lineage"), provided

compelling evidence of clonality over the 52-year period, coupled with single-step acquisition of virulence for resistance genes. It also supported the postulation that two triticale-attacking pathotypes $(34-2,12$ and 34-2,12,13) detected in the early 1980s were derived from pathotype 21-0 via stepwise sequential acquisition of virulence for $\operatorname{Sr} 5, \operatorname{Sr} 11, \operatorname{Sr} 27$, and then SrSatu. Some of the isolates examined that were regarded as members of the race 21/34 lineage based on pathogenicity differed significantly in their SSR genotypes, indicating that they may have originated from processes more complex than simple mutation. This included two isolates of pathotype 21-0, which were collected in 1994 and 2006. Given that sexual recombination in P. graminis is rare or absent in Australia, the cryptic complexity observed could indicate that one or more of these isolates arose as a consequence of asexual recombination.
\end{abstract}

Rust pathogens are known to have great pathogenic variability. This variability is considered to be a major constraint in crop production and disease resistance breeding, and has hindered efforts to control these diseases with genetic resistance. Economic losses due to gradual or sudden pathogenic changes in rust pathogen populations have been well documented. Pathogenic variability in Puccinia graminis f. sp. tritici in Australia has been studied for over 90 years by assaying pathogenicity on differential genotypes (Burdon et al. 1982; Keiper et al. 2003, 2006; Zwer et al. 1992). Evidence of various mechanisms, including sexual recombination, somatic hybridization, exotic introduction, and mutation, has been well documented (Luig and Watson 1970; Park 2007; Watson 1981). Sexual recombination in $P$. graminis f. sp. tritici is generally considered to be rare or absent in Australia due to the rarity of the alternate host barberry (Watson and Luig 1958). On the other hand, a distinct stem rust known locally as the "scabrum" stem rust is believed to have arisen via somatic hybridization between $P$. graminis f. sp. tritici and the rye stem rust pathogen $P$. graminis f. sp. secalis (Luig and Watson 1972; Park and Wellings 2012).

The results of long-term, ongoing pathogenicity surveys have suggested that the introduction of exotic inoculum and mutation are likely the most important factors in generating new virulence in $P$. graminis f. sp. tritici in Australia. $P$. graminis f. sp. tritici isolates found in Australia from 1922 to 2003 were separated into five clonal lineages based on pathogenic characteristics (Park

†Corresponding author: R. F. Park; E-mail address: robert.park@sydney.edu.au

*The $\boldsymbol{e}$-Xtra logo stands for "electronic extra" and indicates that two supplementary tables are published online.

(c) 2017 The American Phytopathological Society
2007). Pathotypes belonging to the standard race $21 / 34$ lineage were all believed to be mutational derivatives from a common founding isolate, identified as pathotype 21-0 and first detected in 1954. This pathotype spread rapidly in the eastern wheat belt during 1954 to 1960 and is considered to have produced many derivative pathotypes via single-step mutation (Park 2007). Derivatives of pathotype 21-0 are believed to be responsible for the most severe rust epidemic in the history of Australian wheat industry, reaching epidemic levels in 1973 to 1974 and causing losses of \$200 to 300 million (Park 2007; Watson and Butler 1984). Mutational derivatives of pathotype 21-0 were also thought to be responsible for severe stem rusting of triticale in Australia in the early 1980s (McIntosh and Singh 1986; Park 2007) and, more recently, the development of virulence for the stem rust resistance gene $\operatorname{Sr} 38$ (Park 2008).

Genetic analyses of pathogen populations and studies of pathogenic variability have helped researchers to understand and trace the pathways by which rust pathogens generate variability. Recent studies of six Australian $P$. graminis f. sp. tritici isolates revealed extensive polymorphism in candidate effector genes based on comparative genomics (Upadhyaya et al. 2015). In view of the importance of the race 21/34 lineage, the availability of microsatellite or simple-sequence repeat (SSR) markers for $P$. graminis $\mathrm{f}$. sp. tritici, and a historic collection of viable isolates of $P$. graminis $f$. sp. tritic $i$ at the Plant Breeding Institute at the University of Sydney, the present study was conducted to examine the relationship between virulence and molecular patterns in selected representative isolates from this lineage collected over a 52-year period.

\section{MATERIALS AND METHODS}

Isolate sampling and purification. Nineteen Australian $P$. graminis f. sp. tritici isolates collected over a 52-year period 
(1954 to 2010) were selected to represent critical pathotypes within the race 21/34 lineage (Park 2007; Watson 1981; Zwer et al. 1992) (Table 1). This included three isolates of pathotype 21-0, collected in 1954 from southern New South Wales and in 1994 and 2006 from Queensland (Table 1).

A single-pustule isolation method was employed to minimize potential genetic heterogeneity within the individual isolates used. Susceptible 'Morocco' wheat was used to increase each isolate. Urediniospores were retrieved from the Plant Breeding Institute Cobbitty Cereal Rust Collection, which are maintained in liquid nitrogen. Each isolate was inoculated onto a standard Australian wheat stem rust differential set (Table 2) in order to confirm its virulence/avirulence pattern and purity.

Inoculation was carried out 7 to 10 days after sowing, when the first leaf of seedlings had fully emerged. Urediniospores were suspended in light mineral oil (ISOPAR L Fluid; ExxonMobil Chemical Company) and atomized above the seedlings using a pressure-pack unit filled with hydrocarbon propellant in a closed inoculation chamber. The pressure-pack unit was sterilized with $70 \%$ ethanol and rinsed in water thoroughly between each inoculation to minimize cross contamination. The inoculated seedlings were kept in the inoculation chamber for approximately $10 \mathrm{~min}$ to allow the urediniospores to settle on the plants. Care was taken to avoid application of the mixture of inoculum and light mineral oil directly onto the plants in order to avoid burning of leaves. The inoculated seedlings were then moved to an incubation room. Pots were incubated in isolation at $100 \%$ relative humidity for $48 \mathrm{~h}$, then transferred to a microclimate room. The seedling reaction or infection type (IT) was evaluated 12 to 14 days after inoculation, when disease symptoms were well developed on the first leaves. The IT was described according to a 0-to-4 scale (McIntosh et al. 1995).
After confirmation based on the knowledge of pathogenicity on the differential genotypes, four single pustules of each isolate were selected, carefully collected, and then increased separately in individual pots of Morocco seedlings by wiping the pustules along the healthy leaves. Inoculation and scoring method were the same as previously described. Urediniospores were collected and dried over silica gel. A small amount was used to test the purity of each single pustule of the isolate, and the remainder was stored in a $-80^{\circ} \mathrm{C}$ freezer. The single pustule isolates that were found to be pure were used for further pathogenicity and molecular analyses.

Characterization of pathogenicity. Although the pathogenicity of all isolates examined was known from previous studies, tests were repeated in the present study to ensure that each isolate was pure. The pathogenicity of each isolate was characterized by infecting differential set at the seedling stage under greenhouse conditions.

In all, 12 to 15 seeds of genotypes in the differential set were sown in a plastic pot $(9.5 \mathrm{~cm}$ in diameter) filled with potting mixture consisting of $20 \%$ coarse sand and $80 \%$ pine bark fines. Pots were fertilized with a complete soluble fertilizer (Aquasol) at an approximate concentration of $3 \mathrm{~g} /$ liter of water before sowing. They were then placed in a disease-free microclimate room at 17 to $20^{\circ} \mathrm{C}$ under natural light to allow seed to geminate and grow. Inoculation was carried out and the IT was scored as previously described.

Molecular characterization. DNA extraction from urediniospores. The cetyltrimethylammonium bromide (CTAB) method was employed to extract DNA from desiccated urediniospores. Briefly, 20 to $30 \mathrm{mg}$ of urediniospores of each isolate was weighed in a sterile $1.5-\mathrm{ml}$ Lysing Matrix C tube (MP Biomedicals). Next, $1 \mathrm{ml}$ of $2 \times$ CTAB extraction buffer $(2 \%$ [wt/vol] CTAB, $100 \mathrm{mM}$ Tris- $\mathrm{HCl}$ [pH 8.0], $20 \mathrm{mM}$ EDTA, $1.4 \mathrm{M} \mathrm{NaCl}$, and 1\% [wt/vol]

TABLE 1. Accession number (Plant Breeding Institute Cobbitty culture number), pathotype, virulence spectrum, geographic origin, and year of collection of 19 Australian isolates of Puccinia graminis f. sp. tritici used to study pathogenicity and genetic diversity

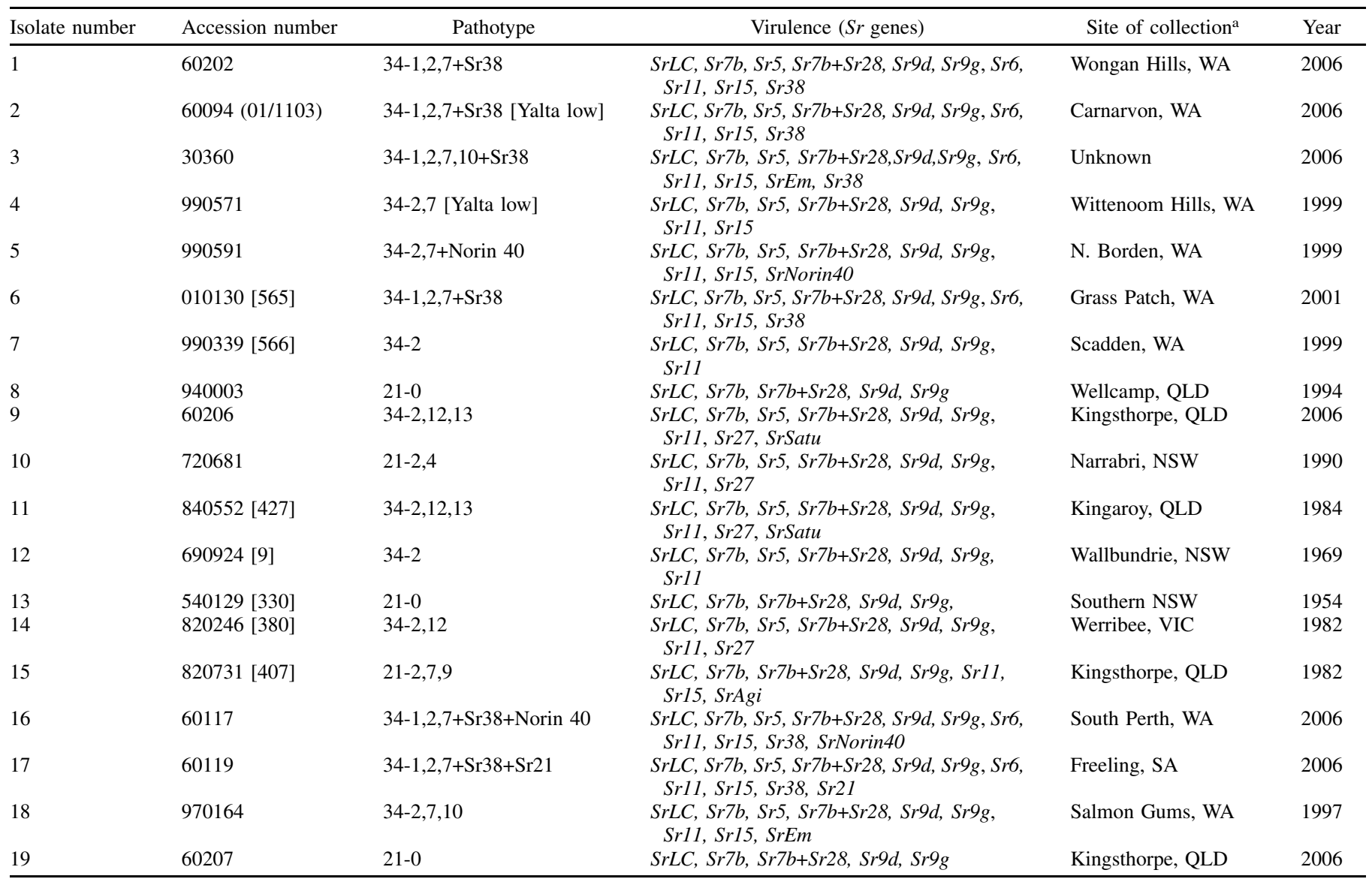

a WA = West Australia, QLD = Queensland, NSW = New South Wales, VIC = Victoria, and SA = South Australia. 
polyvinylpyrrolidone) was added to each tube and mixed well by inversion. The tubes were then incubated on ice for $2 \mathrm{~min}$ before being transferred to a bead beater (Fastprep 100; Thermo Savant Bio101), in which they were shaken for $15 \mathrm{~s}$ at speed setting 6 . Following incubation on ice for $3 \mathrm{~min}$, the tubes were again placed in the FastPrep machine and shaken for $20 \mathrm{~s}$ at speed setting 6, and again returned to ice. This process disrupted spore cell walls and released DNA and proteins.

Tubes were then incubated in a water bath at $65^{\circ} \mathrm{C}$ for $30 \mathrm{~min}$ to soften the phospholipids in the cell membranes and to denature the DNase to prevent digestion of DNA into small fragments. Tubes were then thoroughly mixed by inversion.

After cooling to room temperature, a phenol-chloroform-isoamyl alcohol extraction was performed twice by adding 0.5 volume $(250 \mu \mathrm{l})$ of cold $\left(4^{\circ} \mathrm{C}\right)$ phenol and 0.5 volume of cold chloroform-isoamyl alcohol $(25: 24: 1 \mathrm{vol} / \mathrm{vol})$ to each tube, and mixing thoroughly by gentle inversion. Tubes were centrifuged at maximum speed $(13,200 \mathrm{rpm})$ for $15 \mathrm{~min}$, the supernatant was transferred into a new 1.5-ml Eppendorf tube, and the same phenol-chloroform-isoamyl alcohol extraction procedure was repeated. Chloroform-isoamyl alcohol extraction was preformed later by adding $500 \mu \mathrm{l}$ of cold chloroform-isoamyl alcohol to each tube and mixing thoroughly by gentle inversion. Tubes were then centrifuged at 13,200 rpm for $20 \mathrm{~min}$ and the supernatant was transferred to a clean $1.5-\mathrm{ml}$ Eppendorf tube. Following the chloroform-isoamyl alcohol extraction, DNA was precipitated by adding a 0.1 volume of $3 \mathrm{M} \mathrm{NaOAc}$ and 1 volume of isopopanol to each tube, followed by overnight storage at $-20^{\circ} \mathrm{C}$.

The following day, tubes were centrifuged at $13,200 \mathrm{rpm}$ for $30 \mathrm{~min}$ and DNA pellets were drained by careful removal of solution

TABLE 2. Differential genotypes used to characterize pathogenicity of isolates of Puccinia graminis f. sp. tritici in Australia

\begin{tabular}{|c|c|}
\hline Series, genotype & Resistance genes \\
\hline \multicolumn{2}{|l|}{ International series } \\
\hline Reliance & $\operatorname{Sr} 5$ \\
\hline Marquis & $S r 7 b$ \\
\hline Acme & $\operatorname{Sr} 9 g$ \\
\hline Emmer & $\mathrm{Sr} 9 \mathrm{e}$ \\
\hline Einkorn & $\operatorname{Sr} 21$ \\
\hline Line $S$ & Sr13, Sr17 \\
\hline \multicolumn{2}{|l|}{ Australian series } \\
\hline 1. McMurachy & $\operatorname{Sr} 6$ \\
\hline 2. Yalta & $\operatorname{Srl1}$ \\
\hline 3. W2402 & $\operatorname{Sr} 7 b, \operatorname{Sr} 9 b$ \\
\hline 4. W1656 & Sr36 \\
\hline 5. Renown & $\operatorname{Sr} 7 b, \operatorname{Sr} 17$ \\
\hline 6. Mentana & Sr8a \\
\hline 7. Norka & $\operatorname{Sr} 15$ \\
\hline 8. Festiguay & Sr30 \\
\hline 9. TAF 2 & SrAgi \\
\hline 10. Entrelago de Montijo & $\mathrm{SrEm}$ \\
\hline 11. Barleta Benvenuto & $\operatorname{Sr} 8 b$ \\
\hline 12. Coorong triticale & Sr27 \\
\hline 13. Satu triticale & SrSatu \\
\hline \multicolumn{2}{|l|}{ Additional genotypes } \\
\hline Ningadhu triticale & SrNin \\
\hline Gatcher & $\operatorname{Sr} 2, \operatorname{Sr} 5, \operatorname{Sr} 6, \operatorname{Sr} 8 a, \operatorname{Sr} 12$ \\
\hline Combination X & $\operatorname{Sr} 7 b, \operatorname{Sr} 9 b$ \\
\hline Kite & $\operatorname{Sr} 26$ \\
\hline Agent & $S r 24$ \\
\hline Norin 40 & SrNorin40 \\
\hline Cook & Sr5, Sr6, Sr8a, Sr36 \\
\hline Banks & $\operatorname{Sr} 5, \operatorname{Sr} 8 a, \operatorname{Sr} 9 b, \operatorname{Sr} 12, \operatorname{Sr} 30$ \\
\hline Egret & $\operatorname{Sr} 5, \operatorname{Sr} 8 a, \operatorname{Sr} 9 b, \operatorname{Sr} 12$ \\
\hline Mendos & $\operatorname{Sr} 11, \operatorname{Sr} 17, \operatorname{Sr} 36$ \\
\hline Mildress & $\operatorname{Sr} 31$ \\
\hline Mokoan & $\operatorname{Sr} 9 b$ \\
\hline W3534 & $S r 22$ \\
\hline W3763 & $\operatorname{Sr} 32$ \\
\hline Sr35 & Sr35 \\
\hline Trident & $\operatorname{Sr} 38$ \\
\hline
\end{tabular}

from each tube. The pellets were then washed with $70 \%$ ethanol and centrifuged at 13,200 rpm for $15 \mathrm{~min}$. After centrifugation, excess ethanol was removed by carefully decanting and pellets were air dried, resuspended in $50 \mu \mathrm{l}$ of double-distilled (dd) $\mathrm{H}_{2} \mathrm{O}$, and stored at $4{ }^{\circ} \mathrm{C}$ overnight. The following day, $5 \mu \mathrm{l}$ of RNase A $(10 \mathrm{mg} / \mathrm{ml})$ was added to each tube and tubes were incubated at $37^{\circ} \mathrm{C}$ for $1 \mathrm{~h}$. The DNA concentration was determined with the ND-1000 Nanodrop Spectrophotometer (Thermo Fisher Scientific) and visualized by $2 \%$ agarose gel electrophoresis. DNA stock solutions were stored at $-20^{\circ} \mathrm{C}$ and a working solution of each isolate at $10 \mathrm{ng} /$ $\mu \mathrm{l}$ was prepared for use in the SSR analysis.

SSR primers. Approximately 50 SSR primer pairs (Karaoglu et al. 2013), ranging from di- to penta-nucleotides in motif type and 150 to $450 \mathrm{bp}$ in size, were screened for their abilities to reveal polymorphisms among the $19 \mathrm{P}$. graminis $\mathrm{f}$. sp. tritici isolates. Nine primer pairs with the ability to produce highly repeatable polymorphic DNA bands were selected (Table 3).

Polymerase chain reaction amplification and polymorphic band scoring. Polymerase chain reaction (PCR) was carried out in a 96-well plate in a $25-\mu \mathrm{l}$ volume, comprising $25 \mathrm{ng}$ of genomic DNA template, $10 \mathrm{ng}$ of each primer, $10 \mathrm{mM}$ Tris- $\mathrm{HCl}$ (pH 8.3), $50 \mathrm{mM}$ $\mathrm{KCl}, 1.5 \mathrm{mM} \mathrm{MgCl}_{2}, 0.2 \mathrm{mM}$ each of dNTP(Boehringer Mannheim), $3 \mathrm{mM}$ magnesium acetate, and $2.5 \mathrm{U}$ of AmpliTaq DNA polymerase (Applied Biosystems).

PCR was performed in an Eppendorf Mastercycler (Eppendorf) with initial denaturation at $94^{\circ} \mathrm{C}$ for $4 \mathrm{~min}$; followed by 35 cycles of denaturation at $94^{\circ} \mathrm{C}(30 \mathrm{~s})$, annealing at $55^{\circ} \mathrm{C}(30 \mathrm{~s})$, and extension at $72^{\circ} \mathrm{C}(1 \mathrm{~min})$; followed by a final extension at $72^{\circ} \mathrm{C}(7 \mathrm{~min})$.

Amplified products were resolved by agarose gel electrophoresis and nine loci were identified to have good levels of polymorphism. Forward primers for these nine loci were then $5^{\prime}$ labeled by incorporating either of the fluorophore dyes 6FEM, VIC, NED, or PET (Applied Biosystems). The number of alleles for each SSR locus was scored using the Peak Scanner Software v1.0 (Applied Biosystems).

Data analysis. The binary codes "1" and " 0 " were used to convert the obtained data to represent the presence or absence, respectively, of a specific band in regard to SSR assessment for each isolate. Cluster analysis was performed to produce a dendrogram using the software program PAST, version 3.11 (Hammer et al. 2001). The Paired Group algorithm was used in the cluster analysis based on a distance matrix that was calculated according to Jaccard's similarity coefficient GS $(i j)=a /(a+b+c)$, where GS $(i j)$ stands for the genetic similarity between individuals $i$ and $j, a$ is the number of bands shared by both isolates, and $b$ and $c$ are the number of bands that are present in one isolate but absent in the other. The robustness of the Paired Group dendrogram was assessed by bootstrap analyses with 1,000 replicates using the PAST program (Hammer et al. 2001).

\section{RESULTS}

Pathogenic variability. The virulence characteristics of 19 isolates of $P$. graminis f. sp. tritici were obtained from pathogenicity tests on standard differential genotypes (Table 1). All pathotypes from the 21/34 lineage tested in the present study produced identical IT on the international wheat stem rust differential set, which includes 'Marquis' $(\mathrm{Sr} 7 b)$, 'Acme' $(\mathrm{Sr} 9 g)$, 'Emmer' $(\mathrm{Sr} 9 \mathrm{e})$, 'Einkorn' (Sr21), and 'Line S' (Sr13,Sr17), except 'Reliance' (Sr5), on which race 21 isolates were avirulent and race 34 isolates were virulent. A hypothetical evolutionary pathway of pathotypes selected to represent the 21/34 lineage based on the pathogenic variation observed was proposed (Fig. 1).

Molecular polymorphism. Nine primer pairs were selected based on their abilities to reproducibly amplify specific DNA bands that were polymorphic between the $P$. graminis f. sp. tritici isolates (Table 3). From the 19 isolates used in the present study (Table 1), 29 alleles were amplified. The number of alleles per locus ranged from two to four (Supplementary Table S1). Loci PgSUN36, PgSUN42, 
PgSUN46, PgSUN43, and PgSUN44 generated polymorphic bands of different sizes and distinguished four genotypes among the 19 P. graminis f. sp. tritici isolates that fell into the same subgroup for each primer pair. Three genotypes were distinguished with primer pairs for loci PgSUN47 and two genotypes were differentiated with the primer pairs for loci PgSUN3, PgSUN22, PgSUN47, and PgSUN57.

Molecular variation detected with these nine primer pairs not only was present between different pathotypes but also was found between different isolates of the same pathotype that produced identical IT on the differential set used. For example, of the three isolates of pathotype 21-0 examined, all produced identical IT on the differential set but differed in SSR genotype. Similar polymorphisms were also found between isolates of pathotype 34-2 (isolates 7 and 12) and pathotype 34-1,2,7+Sr38 (isolates 1, 2, and 6).

The dendrogram using the Jaccard similarity coefficient based on unweighted pair-group method with arithmetic means analysis is given in Figure 2. The distance matrix that the dendrogram is based on is given in Supplementary Table S2. The cluster analysis of the molecular data revealed five distinct groups, separated at approximately $50 \%$ similarity or less. The five major clusters (MC) were as follows.

MC1 comprised a single isolate, number 19 (pathotype 21-0), which was separated from all the other isolates at approximately $6 \%$ similarity (Fig. 2). This isolate was collected in 2006 in Queensland (Table 1) and was designated as 21-0 based on its pathogenicity on the differential set. This cluster was supported by a bootstrap value of $100 \%$.

MC2, supported by a bootstrap value of $100 \%$, comprised two isolates that were identical in their SSR genotype (Fig. 2). It included one isolate collected in 2006 (isolate 17, pathotype 34$1,2,7+\mathrm{Sr} 38+\mathrm{Sr} 21$ ), and one collected in 1997 (isolate 18, pathotype $34-2,7,10)$.

MC3 comprised seven isolates that were identical in their SSR genotypes and was supported by a bootstrap value of $100 \%$. The seven isolates in MC2 were all members of the standard race 21/34 lineage, and included the original isolate of pathotype 21-0 collected in 1954. The other six isolates comprised two collected in 1982 (isolate 14, pathotype 34-2,12 and isolate 15, pathotype 21-2,7,9), two collected in 2006 (isolate 9, 34-2,12,13 and isolate 16, pathotype 34-1,2,7+Sr38+SrNorin40), and two (isolate 12, pathotype 34-2 and isolate 11, pathotype 34-2,12,13) collected in 1969 and 1984 , respectively.

MC4 was the largest cluster and comprised eight isolates that were identical in their SSR genotypes, with a bootstrap value of $100 \%$. It included one collected in 1972 (isolate 10, pathotype
21-2,4), three collected in 1999 (isolate 4, pathotype 34-2,7 ['Yalta' low]; isolate 5, pathotype 34-2,7+Norin 40; and isolate 7, pathotype $34-2$ ), one collected in 2001 [isolate 6 , pathotype $34-1,2,7+\operatorname{Sr} 38$ ), one collected in 2003 (isolate 3, pathotype 34-1,2,7,10+Sr38), and two collected in 2006 (isolate 1, pathotype $34-1,2,7+\operatorname{Sr} 38$ and isolate 2, pathotype 34-1,2,7+Sr38 [Yalta low]).

MC5 comprised a single isolate (isolate 8, pathotype 21-0) that was collected in 1994 in Queensland and was supported by a bootstrap value of $64 \%$.

\section{DISCUSSION}

Based on previous pathogenicity testing, 19 P. graminis f. sp. tritici isolates collected over a 52-year period were selected to represent the standard race 21/34 lineage. All isolates were believed to belong to a single clonal lineage and to have descended from a common ancestor (pathotype 21-0) through simple mutation (Fig. 1). Analyses using nine SSR primer pairs developed specifically for P. graminis f. sp. tritici revealed five SSR genotypes among these 19 isolates, clearly indicating that they are not members of a single clonal lineage and that their origins must be more complex than originally thought.

Despite this complexity, our results did provide compelling evidence of clonality over a long period of time, coupled with single-step acquisition of virulence for resistance genes. One isolate of pathotype 21-0 collected in 1954 (isolate 13) shared the same SSR genotype with six other isolates of race 21/34 that included three triticale-attacking isolates, the most recent being collected in 2006, some 52 years after the collection of isolate 13 (MC 3). These results are consistent with the putative evolutionary pathway (Fig. 1) for the triticale-attacking pathotypes 34-2,12 and 34-2,12,13 derived from pathotype 21-0, involving stepwise sequential acquisition of virulence for the resistance genes $\mathrm{Sr} 5, \mathrm{Sr} 11, \mathrm{Sr} 27$, and then SrSatu.

In addition to isolate 13 , two other isolates ( 8 and 19) designating as pathotype 21-0 based on identical IT on the differential set were included in this study. All three isolates differed in their SSR genotype, indicating that this pathotype is genetically heterogeneous, whereas isolate 13 (collected in 1954) fell into MC3, isolate 8 (collected in 1994) was included in MC5, and isolate 19 (collected in 2006) was separated from all other isolates at a comparatively very low similarity of approximately $17 \%$ (Fig. 2). Pathotype 21 0 was first detected in 1954 and increased rapidly to become the dominant $P$. graminis f. sp. tritici pathotype in southern New South Wales, Victoria, and Tasmania (Watson and Luig 1958). Although Watson (1958) proposed that pathotype 21-0 originated from

TABLE 3. Sequence, repeat motif, size range, and annealing temperatures $(\mathrm{Tm})$ of nine simple-sequence repeat primer pairs used for molecular characterization of isolates of Puccinia graminis f. sp. tritici ${ }^{\mathrm{a}}$

\begin{tabular}{|c|c|c|c|c|}
\hline Locus & Primer sequences $\left(5^{\prime}-3^{\prime}\right)$ & Repeat motif & Size range (bp) & $\operatorname{Tm}\left({ }^{\circ} \mathrm{C}\right)$ \\
\hline PgSUN3 & $\begin{array}{l}\text { F:AGCAGCGTCGCCATAACAATA } \\
\text { R. GTAGACTGGCCGTACA ACAC }\end{array}$ & $(\mathrm{CAT})_{13}$ & $360-381$ & 55 \\
\hline PgSUN22 & $\begin{array}{l}\text { F:GTGTTGAGGGTGAGGATAGA } \\
\text { R:GTGCCCGATAAAAAAAGAAA }\end{array}$ & $(\mathrm{AAGA})_{18}$ & $291-295$ & 55 \\
\hline PgSUN36 & $\begin{array}{l}\text { F:CGGGGTGACTGAAGATAGAG } \\
\text { R:CCCTTTCTACCTCCTTACTT }\end{array}$ & $\begin{array}{c}(\text { TTTGT })_{9} \\
\ldots\end{array}$ & $304-325$ & 55 \\
\hline PgSUN42 & $\begin{array}{l}\text { F:GGGGGGTGACTGAAAAATA } \\
\text { R:CCСТTTTCTACСТCСТTACTT }\end{array}$ & $\begin{array}{c}(\text { TTTGG })_{12} \\
\ldots\end{array}$ & $308-329$ & $\begin{array}{l}55 \\
\ldots\end{array}$ \\
\hline PgSUN44 & $\begin{array}{l}\text { F: ATCCGCTGGTAAAGGTGAAA } \\
\text { R:GGGGGGTGACTGAAAGATAA }\end{array}$ & $(\mathrm{AAACA})_{13}$ & $281-301$ & 55 \\
\hline PgSUN46 & $\begin{array}{l}\text { F:GGGGTGACTGAAAGATAAGA } \\
\text { R:CGCTGGTAAAGGTGAAAAAC }\end{array}$ & $\begin{array}{c}(\text { TGTTT })_{13} \\
\ldots\end{array}$ & $280-295$ & 55 \\
\hline PgSUN47 & $\begin{array}{l}\text { F: ACCGCTATCAACCCTAATCA } \\
\text { R: GGAGGAAAAGCCGAGAATC }\end{array}$ & $\begin{array}{c}(\mathrm{CTCTT})_{14} \\
\ldots\end{array}$ & $\begin{array}{c}283-288 \\
\ldots\end{array}$ & 55 \\
\hline PgSUN57 & $\begin{array}{l}\text { F:CGTGAAAAGGTGCTACATCT } \\
\text { R:GGTGAGAAGAGGCATACTAA }\end{array}$ & $\begin{array}{c}(\text { ATATC })_{8} \\
\ldots\end{array}$ & $\begin{array}{c}246-251 \\
\ldots\end{array}$ & $\begin{array}{l}55 \\
\ldots\end{array}$ \\
\hline
\end{tabular}

a All loci listed, except PgSUN57, are from Karaoglu et al. (2013). 
infected Berberis spp. in Tasmania and then migrated north to mainland Australia, Luig (1977) suggested that it originated from Africa. Watson and Luig (1963) isolated pathotype 21-0 (as pathotype 21ANZ-1) from Agropyron spp. growing in close proximity to Berberis spp. in Tasmania. Therefore, it was possible that pathotype 21-0 originated from Berberis spp. and that more than one genotype was generated, or that one or more genotypes arose from Berberis spp. and another was introduced to Australia from Africa. The avirulence of this pathotype for many resistance genes (only virulent for $S r 7 b$ and $S r 9 g$ in the Australasian $P$. graminis f. sp. tritici differential set) suggests that it could not have survived on the dominant wheat cultivars grown in northeastern Australia since at least the 1970s because most of them carried effective resistance genes such as $\mathrm{Sr} 5, \mathrm{Sr} 6, \mathrm{Sr} 8 a, \mathrm{Sr} 9 b, \mathrm{Sr} 11$, Sr17, Sr24, Sr26, Sr30, and Sr36 (Zwer et al. 1992). Therefore, the isolates recovered in 1994 and 2006 must have survived mainly on susceptible grass species or possibly barley. Somatic hybridization between $P$. graminis f. sp. tritici and $P$. graminis f. sp. secalis is known to occur (the scabrum rust) and the distinctiveness of the 2006 isolates, coupled with their avirulence on many of the resistance genes in the differential set, raises the possibility that they could be isolates of scabrum stem rust. Further studies that include isolates of $P$. graminis f. sp. secalis are needed to determine whether this is the case. Preliminary studies with the SSR primers used in the present study have demonstrated that they are polymorphic among Australian $P$. graminis f. sp. secalis isolates (H. Karaoglu, unpublished).

Pathotype 34-2 was present in Western Australia during the 1970s and, although detected commonly in annual pathogenicity surveys from 1978 to 1982, it was not detected in surveys from 1983 to 1989 (Zwer et al. 1992). It was detected again in the 1990 annual pathogenicity survey, after which it and a series of putative mutational derivative pathotypes were detected (R. Park, unpublished) (Fig. 1). Pathotype 34-1,2,7, first detected in 2000, was regarded as a single-step mutational derivative of pathotype 34-2,7, with added virulence for Sr6. Pathotype

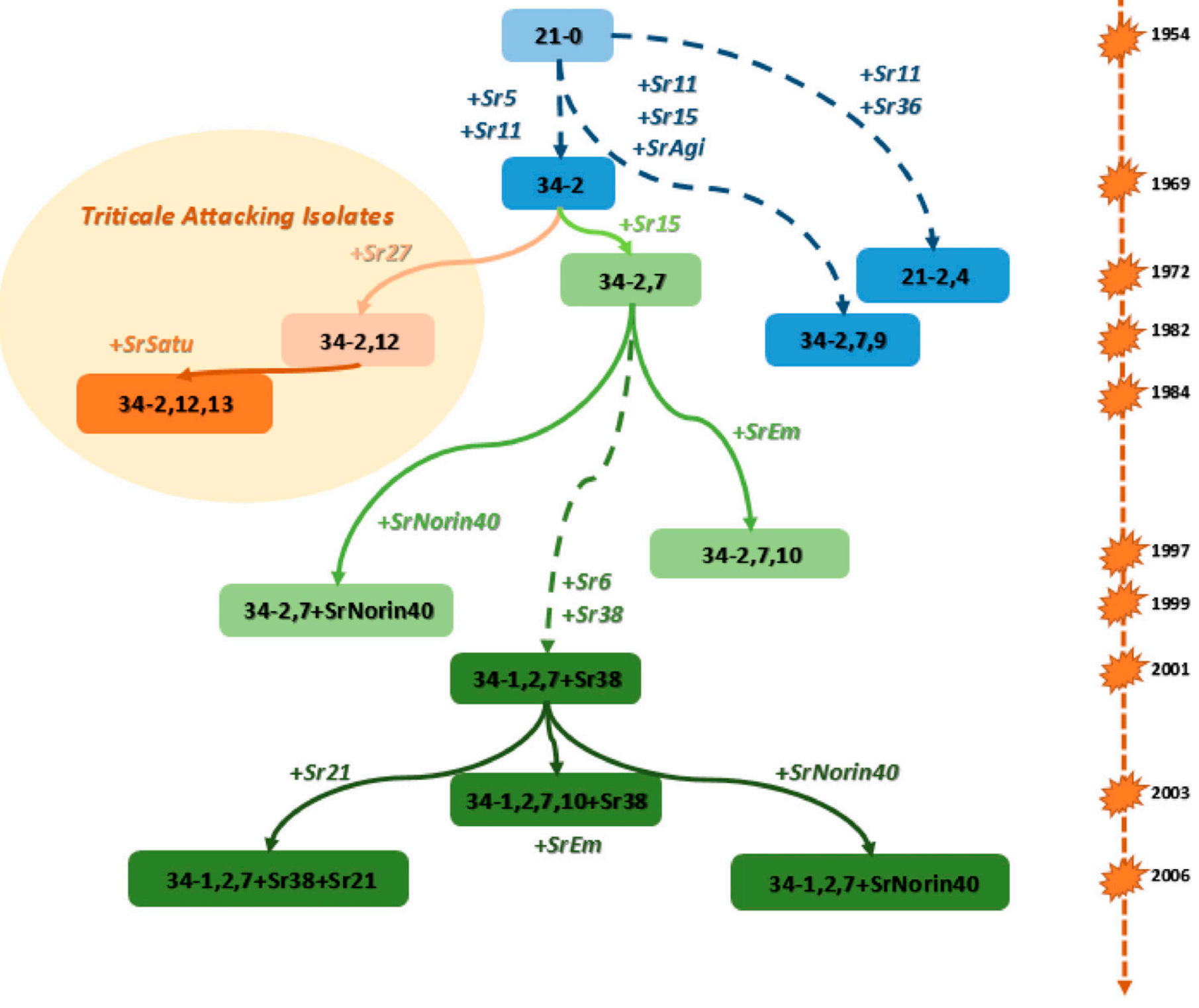

Fig. 1. Proposed evolutionary pathways of specialization in selected pathotypes from the standard race 21/34 lineage of Puccinia graminis f. sp. tritici in Australia based on pathogenicity testing. Solid and dotted lines indicate the possibility of single or multiple mutations, respectively, at loci governing pathogenicity. Timeline indicated the first detection year for each pathotype. 


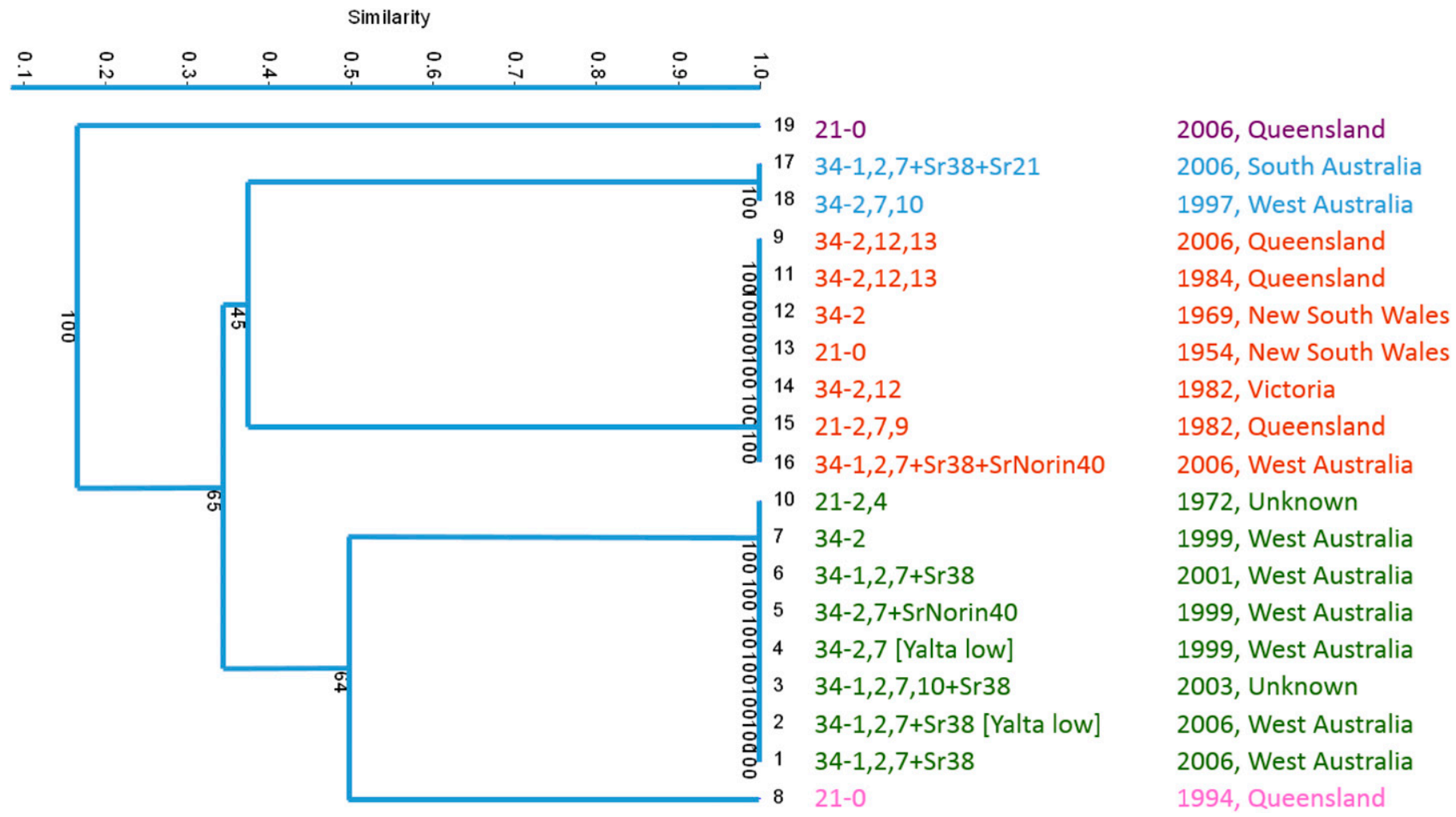

Fig. 2. Dendrogram of 19 isolates of Puccinia graminis f. sp. tritici collected in Australia from 1954 to 2006, based on data pooled from nine simple-sequence repeat primer pairs. The Paired Group algorithm was used in the cluster analysis program of statistical package PAST, version 3.11 (Hammer et al. 2001). The analysis used a similarity matrix based on the Jaccard similarity coefficient. Numbers given to dendrogram branches are the percentage of bootstrap values supporting the cluster.

34-1,2,7+Sr38 was first detected in Western Australia in 2001 and, again, was regarded as a mutational derivative of pathotype 34-1,2,7 with added virulence for $S r 38$. This pathotype increased rapidly and became the most commonly isolated pathotype from 2003 to 2005, presumably because of the cultivation of 'Camm' wheat with Sr38 (Park 2007). Nine isolates representing pathotypes within race 34 collected from Western Australia from 1999 to 2006 (isolates 1 to 7,16 , and 18) and one isolate of pathotype $34-1,2,7+\operatorname{Sr} 38+\operatorname{Sr} 21$ collected from South Australia in 2006 (isolate 17) were, therefore, expected to share the same SSR genotype. However, three different SSR genotypes were identified, and two were also distinct from the standard race 21/34 lineage based on the isolate of pathotype 21-0 collected in 1954 (MC3), indicating that they were not derived from this pathotype via simple mutation. Of particular interest was the separation of isolates with virulence for $\operatorname{Sr} 38$ into three MC: MC2, MC3, and MC5 (Fig. 2). These results further indicated that the derivation of these pathotypes was not as simple as the pathogenicity data suggested and, moreover, that virulence to $\operatorname{Sr} 38$ likely arose as a result of at least two independent mutational events or that a single mutation to virulence was followed by genetic reassortment to generate a different genotype. Luig (1985) reported that $P$. graminis f. sp. secalis isolates virulent for $\mathrm{Sr} 11$ produce "semi-susceptible" IT on Yalta. Two isolates ( 2 and 4) in MC4 produced low but intermediate IT on Yalta (IT $22+\mathrm{C}$ ); thus, it is possible that isolates in this cluster were derived from a somatic hybridizational event involving pathotype $34-1,2,7+\operatorname{Sr} 38$ and an isolate of $P$. graminis $\mathrm{f}$. sp. secalis.

One isolate of pathotype $34-1,2,7+\operatorname{Sr} 38+\operatorname{Sr} 21$ (isolate 17) collected from South Australia in 2006 was identical in its SSR genotype to isolate 18 of race 34 collected from Western Australia, supporting previous evidence that has implied rust inoculum exchange between the western and eastern wheat- growing regions in Australia (Luig and Watson 1970; Zwer et al. 1992).

Microsatellite- or SSR-based profiling, due to its low cost, high sensitivity, high throughput, short turnover time, and technique dependence when compared with sequencing technology, has previously been routinely used as a powerful molecular tool for studying many organisms, including wheat, which has one of the most challenging hexaploid genomes in regard to marker-assisted selection and for rust pathogen detection, identification, and characterization in many countries (Bailey et al. 2015; Berlin et al. 2013; Karaoglu et al. 2013; Somers et al. 2004; Song et al. 2005; Visser et al. 2009, 2016). The SSR markers used in the present study were proven to be very informative in clarifying genetic diversity among selected Australian P. graminis f. sp. tritici isolates, providing a more detailed indication of evolutionary relationships within this pathogen than previous attempts that used other marker systems such as amplified fragment length polymorphism (Keiper et al. 2006; Szabo 2007). The information obtained from the present study clearly demonstrated that P. graminis f. sp. tritici populations in Australia were genetically more complex than previously thought. These results formed a sound base for further work using newer technologies such as wholegenome sequencing in order to obtain a better understanding on the genetic structure and the causal factors of genetic variation of $P$. graminis f. sp. tritici populations in Australia.

\section{ACKNOWLEDGMENTS}

This work was financially supported by the Grains Research and Development Corporation, Australia, and a generous donation to the University of Sydney by the Coffey family. J. Zhang acknowledges the National Science Foundation of the United States for providing the postgraduate scholarship that enabled this study to be initiated and completed. We thank M. Williams, P. Kankwatsa, S. Hoxha, and M. Pietilainen of Plant Breeding Institute, The University of Sydney, for their technical assistance. 


\section{LITERATURE CITED}

Bailey, J., Karaoglu, H., Wellings, C. R., and Park, R. F. 2015. PCR-based simple sequence repeat markers for diagnostic identification of major clonal lineages of Puccinia striiformis f. sp. tritici and related stripe rust pathogens in Australia. Australas. Plant Pathol. 44:97-103.

Berlin, A., Samils, B., Djurle, A., Wirse, H., Szabo, L., and Yuen, J. 2013. Disease development and genotypic diversity of Puccinia graminis $\mathrm{f}$. sp. avenae in Swedish oat fields. Plant Pathol. 62:32-40.

Burdon, J. J., Marshall, D. R., Luig, N. H., and Gow, D. J. S. 1982. Isozyme studies on the origin and evolution of Puccinia graminis f. sp. tritici in Australia. Aust. J. Biol. Sci. 35:231-238.

Hammer, Ø., Harper, D. A. T., and Ryan, P. D. 2001. PAST: Paleontological statistics software package for education and data analysis. Palaeontol. Electron. 4:1-9.

Karaoglu, H., Lee, C. M. Y., and Park, R. 2013. Simple sequence repeats in Puccinia graminis: Abundance, cross-formae speciales and intra-species utility, and development of novel markers. Australas. Plant Pathol. 42:271-281.

Keiper, F. J., Haque, M. S., Hayden, M. J., and Park, R. F. 2006. Genetic diversity in Australian populations of Puccinia graminis f. sp. avenae. Phytopathology 96:96-104.

Keiper, F. J., Hayden, M. J., Park, R. F., and Wellings, C. R. 2003. Molecular genetic variability of Australian isolates of five cereal rust pathogens. Mycol. Res. 107:545-556.

Luig, N. H. 1977. The Establishment and success of exotic strains of Puccinia graminis tritici in Australia. Proc. Ecol. Soc. Aust. 10:89-96.

Luig, N. H. 1985. Epidemiology in Australia and New Zealand. Pages 301-328 in: The Cereal Rusts, Vol. 2. W. R. Bushnell and A. P. Roelfs, eds. Academic Press, Inc., New York.

Luig, N. H., and Watson, I. A. 1970. The effect of complex genetic resistance in wheat on the variability of Puccinia graminis f. sp. tritici. Proc. Linn. Soc. N. S. W. 95:22-45.

Luig, N. H., and Watson, I. A. 1972. The role of wild and cultivated grasses in the hybridization of formae speciales of Puccinia graminis. Aust. J. Biol. Sci. 25: 335-342.

McIntosh, R. A., and Singh, S. J. 1986. Rusts-Real and potential problems for triticale. Pages 199-207. In: Int. Triticale Symp. N. L. Darvey, ed. Australian Institute of Agricultural Science, Sydney, NSW, Australia.

McIntosh, R. A., Wellings, C. R., and Park, R. F. 1995. Wheat Rusts: An Atlas of Resistance Genes. CSIRO Australia, Sydney, Kluwer Academic Publishers, Dordrecht, The Netherlands.
Park, R. F. 2007. Stem rust of wheat in Australia. Aust. J. Agric. Res. 58: 558-566.

Park, R. F. 2008. Breeding cereals for rust resistance in Australia. Plant Pathol. 57:591-602.

Park, R. F., and Wellings, C. R. 2012. Somatic hybridisation in the Uredinales. Annu. Rev. Phytopathol. 50:219-239.

Somers, D. J., Isaac, P., and Edwards, K. 2004. A high-density microsatellite consensus map for bread wheat (Triticum aestivum L.). Theor. Appl. Genet. 109:1105-1114.

Song, Q. J., Shi, J. R., Singh, S., Fickus, E. W., Costa, J. M., Lewis, J., Gill, B. S., Ward, R., and Cregan, P. B. 2005. Development and mapping of microsatellite (SSR) markers in wheat. Theor. Appl. Genet. 110:550-560.

Szabo, L. J. 2007. Development of simple sequence repeat markers for the plant pathogenic rust fungus, Puccinia graminis. Mol. Ecol. Notes 7:92-94.

Upadhyaya, N. M., Garnica, D. P., Karaoglu, H., Sperschneider, J., Nemri, A., Xu, B., Mago, R., Cuomo, C. A., Rathjen, J. P., Park, R. F., Ellis, J. G., and Dodds, P. N. 2015. Comparative genomics of Australian isolates of the wheat stem rust pathogen Puccinia graminis f. sp. tritici reveals extensive polymorphism in candidate effector genes. Front. Plant Sci. 5:759.

Visser, B., Herselman, L., and Pretorius, Z. A. 2009. Genetic comparison of Ug99 with selected South African races of Puccinia graminis f. sp. tritici. Mol. Plant Pathol. 10:213-222.

Visser, B., Herselman, L., and Pretorius, Z. A. 2016. Microsatellite characterisation of South African Puccinia striiformis race. S. Afr. J. Plant Soil 33: 161-166.

Watson, I. A. 1958. The present status of breeding disease resistant wheats in Australia. Agric. Gaz. N. S. W. 72:145-146.

Watson, I. A. 1981. Wheat and its rust parasites in Australia. Pages 129-147 in: Wheat Science-Today and Tomorrow. L. T. Evans and W. J. Peacock, eds. Cambridge University Press, Cambridge.

Watson, I. A., and Butler, F. C. 1984. Wheat rust control in Australia: National Conferences and Other Initiatives and Developments. The University of Sydney, Sydney, NSW, Australia.

Watson, I. A., and Luig, N. H. 1958. Widespread natural infection of barberry by Puccinia graminis in Tasmania. Proc. Linn. Soc. N. S. W. 106:207-208.

Watson, I. A., and Luig, N. H. 1963. The classification of Puccinia graminis var. tritici in relation to breeding resistant varieties. Proc. Linn. Soc. N. S. W. $88: 235-258$.

Zwer, P. K., Park, R. F., and McIntosh, R. A. 1992. Wheat stem rust in Australia-1969-1985. Aust. J. Agric. Res. 43:399-431. 